\title{
DRAKEN EN LANGE LIJZEN. CHINEES PORSELEIN UIT DE EIGEN COLLECTIE (GRONINGEN)
}

Van 30 juni 2012 tot en met 1 september 2013 is in het Groninger Museum de tentoonstelling Draken en lange Lijzen. Chinees Porselein uit de eigen collectie te zien. De expositie toont ruim 200 mooie en kenmerkende stukken. Daarbij wordt uitleg gegeven over de periode waarin het gemaakt werd, welke speciale kenmerken het heeft en welke plaats het innam in het totale assortiment van exportporselein voor Nederland. Ook wordt aandacht besteed aan de versieringen, hun betekenis en aan merken op porselein. Diverse exemplaren worden voor het eerst getoond.

Er zijn diverse soorten porselein te zien, zoals Kraakporselein, Overgangsporselein, Kangxi blauw-wit, Chine de Commande, Famille Rose, Mandarijn, Blane de Chine en Yixing. Daarnaast toont het Groninger Museum porselein uit scheepswrakken. Tenslotte is er een reeks figuren van Chinese goden en wijsgeren, van figuren voor de Europese markt en van slanke Chinese vrouwen, de zogenaamde 'Lange Lijzen'.

\section{Statusverhogend}

Bijna al dit porselein - daterend uit $17^{e}$ en $18^{e}$ eeuw - is via de VOC of particuliere handelaren uit China naar Nederland verscheept. In de $17^{\mathrm{e}}$ eeuw was porselein nog iets bijzonders. De samenstelling van het materiaal en de fabricage van het porselein waren een raadsel. Porselein was exotisch, relatief duur en versterkte daardoor de status van de eigenaar. In het begin van de $18^{\mathrm{e}}$ eeuw werd het geheim van het porselein-maken in Duitsland ontdekt en daarna moest het Chinese porselein concurreren met Europees porselein. De prijs ging omlaag en het assortiment aan versieringen en vormen werd enorm uitgebreid. Uit opgravingen blijkt dat in Nederland bijna iedereen wel een stuk porselein in huis had. Ook nu nog komt het in heel veel huishoudens voor. Chinees porselein vormde een essentieel element in het Nederlandse interieur, meer dan waar ook ter wereld.

Oud-conservator en porseleindeskundige Christiaan Jörg is de samensteller van deze tentoonstelling.

\section{Te zien}

Groninger Museum. Op maandag gesloten.

Juni 2012 - 1 september 2013 


\section{Vereniging van Vrienden der Aziatische Kunst}

www.vvak.nl

\section{ERELID}

Dr. J. Fontein

\section{BESTUUR}

Mr. J.M. Boll, voorzitter

Ir. A.A. Holst, lid

Mw. drs. R.H.M. van der Poel, secretaris

Mw. drs. R.E. Roskam, lid

Drs. H. Schulte Nordholt, lid

Drs. T.T. Wen, penningmeester

\section{RAAD VAN ADVIES}

Mr. W.L.J. Bröcker

Prof.dr. C.J.A. Jörg

Drs. H.E. Kreijger

Mr. E.M.W. de Lange

Mr. drs. A. Ott

J. Polak

Mw. dr. C.E. van Rappard-Boon

J.J.N. Rost Onnes

Mw. dr. R.L. Steenbergen

CORPORATE MEMBER / SPONSOR

Ottema Kingma Stichting Leeuwarden

International Institute for Asian Studies (IIAS)

\section{Lidmaatschap}

- Gewoon lidmaatschap: $€ 60,-$ per kalenderjaar

- Jongerenlidmaatschap ( $\mathrm{t} / \mathrm{m} 25$ jaar):

$€ 25,-$ per kalenderjaar

- Sponsor/corporate member:

(tenminste) $€ 600,-$ per kalenderjaar

Het lidmaatschap van de Vereniging loopt van 1 januari tot en met 31 december. Opzegging van het lidmaatschap kan alleen schriftelijk via het bestuur (vvak@denboerenvink.nl). Opzegging voor een komend jaar dienen voor 31 december van het lopende jaar door het bestuur ontvangen te zijn. Wanneer het lidmaatschap in de loop van het verenigingsjaar wordt beëindigd, blijft de bijdrage voor het hele jaar verschuldigd.

\section{Als WAK-lid}

- ontvangt u vier maal per jaar het tijdschrift Aziatische Kunst

- krijgt u ieder kwartaal de VVAK-Nieuwsbrief in de bus

- wordt u uitgenodigd voor lezingen en bijeenkomsten

- krijgt u een lidmaatschapskaart, waarmee u gratis toegang heeft tot het Rijksmuseum Amsterdam en de activiteiten van de VVAK

\section{Ledenadministratie en secretariaat Vereniging} Jac's den Boer en Vink bv

Postbus 43

2850 AA Haastrecht

T: 0182501696

E: vvak@denboerenvink.nl

\section{Advertenties}

Om te adverteren in Aziatische Kunst kunt u contact opnemen met de heer drs. T.T. Wen, penningmeester, e-mail: wentt@xs4all.nl

\section{Bankrekeningnummer}

ING 188285, ten name van Vereniging van Vrienden der Aziatische Kunst, Den Haag.

\section{Kamer van Koophandel}

De Vereniging is ingeschreven bij de Kamer van Koophandel in Amsterdam, onder nummer 40.531.260.

\section{ANBI}

De Vereniging heeft de status van een Algemeen Nut Beogende Instelling. 